\title{
The Incidence of Alternaria Species Associated with Infected Sesamum indicum L. Seeds from Fields of the Punjab, Pakistan
}

\author{
Brian Gagosh Nayyar ${ }^{1 *}$, Steve Woodward ${ }^{2}$, Luis A. J. Mur ${ }^{3}$, Abida Akram ${ }^{1}$, Muhammad Arshad ${ }^{1}$, \\ S. M. Saqlan Naqvi ${ }^{4}$, and Shaista Akhund ${ }^{1}$ \\ ${ }^{1}$ Department of Botany, Pir Mehr Ali Shah Arid Agriculture University, Rawalpindi 46300, Pakistan \\ ${ }^{2}$ Institute of Biological and Environmental Sciences, University of Aberdeen, Cruikshank Building, St. Machar Drive, \\ Aberdeen AB24 3UU, Scotland, UK \\ ${ }^{3}$ Institute of Biological, Rural and Environmental Sciences, Aberystwyth University, Edward Llwyd Building, Penglais \\ Campus, Aberystwyth SY23 3DA, Wales, UK \\ ${ }^{4}$ Department of Biochemistry, Pir Mehr Ali Shah Arid Agriculture University, Rawalpindi 46300, Pakistan
}

(Received on April 10, 2017; Revised on July 9, 2017; Accepted on July 23, 2017)

Sesame (Sesamum indicum) is an important oil seed crop of Asia. Yields can be negatively impacted by various factors, including disease, particularly those caused by fungi which create problems in both production and storage. Foliar diseases of sesame such as Alternaria leaf blight may cause significant yield losses, with reductions in plant health and seed quality. The work reported here determined the incidence of Alternaria species infecting sesame seeds grown in the Punjab, Pakistan. A total of 428 Alternaria isolates were obtained from 105 seed samples and grouped into 36 distinct taxonomic groups based on growth pattern and morphological characters. Isolation frequency and relative density of surface sterilized and non-surface sterilized seeds showed that three isolates (A13, A47 and A215) were the most common morphological groups present. These isolates were further identified using sequencing of the Internal Transcribed Spacer (ITS) region of ribosomal DNA (rDNA) and the Alternaria major allergen gene (Alt a 1). Whilst ITS of rDNA did not resolve the isolates into Alternaria species, the Alt a 1 sequences exhibited $>99 \%$ homology with Alternaria alternata

\footnotetext{
*Corresponding author.

Phone) +92-334-809-8095, FAX) +92-51-9290160

E-mail)brian gagosh@hotmail.com

(c) This is an Open Access article distributed under the terms of the Creative Commons Attribution Non-Commercial License (http:// creativecommons.org/licenses/by-nc/4.0) which permits unrestricted noncommercial use, distribution, and reproduction in any medium, provided the original work is properly cited.
}

Articles can be freely viewed online at www.ppjonline.org.
(KP123850.1) in GenBank accessions. The pathogenicity and virulence of these isolates of Alternaria alternata was confirmed in inoculations of sesame plants resulting in typical symptoms of leaf blight disease. This work confirms the identity of a major source of sesame leaf blight in Pakistan which will aid in formulating effective disease management strategies.

Keywords : Alternaria, Alt a 1 gene, ITS, Punjab, sesame seeds

Handling Associate Editor : Lee, Jungkwan

Sesame (Sesamum indicum L.) is one of the oldest and most important oilseed crops, mainly grown for its oil and protein content (Johnson et al., 1979). This crop is an important source of fats, proteins, vitamins and minerals in the food of rural people, particularly children, throughout the world (Shahidi et al., 2006). Sesame seed contains oil (48 to $60 \%$ ), protein (18 to $23.5 \%$ ), carbohydrate $(13.5 \%$ ), and ash (5.3\%), with a moisture content of approximately 5.2\% (Obiajunwa et al., 2005; Kahyaoglu and Kaya, 2006). Sesame oil contains the antioxidants sesamoline, sesamin and sesamol (Pastorello et al., 2001). Sesame oil is used in cuisine for salad dressings and the manufacturing of margarine, and is a raw ingredient in industry for making paints, varnishes, soaps, perfumes, insecticides, and pharmaceuticals as a vehicle for drug delivery (Grubben and Denton, 2004).

Cultivation of sesame probably originated in the Harappa Valley region of the Indian subcontinent as long as ago as 
pre-3000 BC (Ashri, 2007). Currently, sesame is grown commercially in 76 countries in the world but production is mostly dominated by Asian and African countries (Ashri, 1998). India, Sudan and China are the leading producers of sesame, followed by Myanmar, Nigeria, Ethiopia, Uganda, Mexico, Pakistan, Bangladesh, Thailand, Turkey (FAO, 2014). In Pakistan, sesame is grown in all four provinces, but $89 \%$ of production is in the Punjab, which is considered a major sesame producing area in South Asia (The Financial Daily, 2017).

Numerous microorganisms, especially fungi, pose a challenge to both sesame production and seed storage. Sesame agriculture faces numerous disease problems, including vascular wilt, root rot, leaf blight, leaf spot and damping off in young seedlings (Farhan et al., 2010). Previous reports have shown the presence of Aspergillus and Fusarium in sesame seeds (Mbah and Akueshi, 2000, 2001). However, sesame is also susceptible to leaf blight caused by Alternaria sesami (Kolte, 1985), which is also seed-borne (Richardson, 1979). Leaf diseases of sesame, such as blight diseases caused by Alternaria spp. result in substantial loss in yield and deterioration in quality and vigor of seed (Enikuomehin et al., 2002). Of particular economic importance is leaf blight caused by Alternaria sesami and A. alternata (Chohan, 1978), which also causes seed rot and pre- and post-emergence damping-off, as well as infecting all aerial plant parts, resulting in considerable losses in yield, both qualitative and quantitative (Naik et al., 2004). Alternaria leaf spot of sesame has been recognized as a major biotic pressure of single origin limiting yields (Lubaina and Murugan, 2013). Symptoms of Alternaria leaf blight include the formation of round to irregular spots of up to 10 $\mathrm{mm}$ diameter. Individual spots may coalesce to form large necrotic patches, resulting in premature abscission (Rao and Vijayalakshmi, 2000). Alternaria species are dispersed from region to region through various pathways which include air-borne conidia and adherence of soil to seedlings, farm equipment, or animals (Ojiambo, 1997).

Alternaria species produce non-host specific (e.g., tenuazonic acid (TeA), alternariol (AOH), alternariol monomethyl ether (AME), brefeldin A, tentoxin, zinniol) (Saha et al., 2012) as well as host-specific toxins (Thomma, 2003) which contaminate the product. Consumption of foodstuff contaminated with Alternaria toxins has been implicated in elevated incidence of esophageal carcinoma in humans (Schrader et al., 2001). The wide distribution, high variability and influence of Alternaria spp. on crops and humans warrants accurate identification of the causal agents to formulate effective control and management strategies (Hong et al., 2005b).
The aim of the work described in this paper was to determine the Alternaria species associated with sesame in the Punjab, Pakistan, as an example of the source of yield losses affecting production of this important crop in South Asia. To the best of our knowledge, no such studies have been carried out to date in the Punjab. This basic work on testing seeds for the presence of seed-borne pathogens is an important step in the development of disease management strategies for this crop.

\section{Materials and Methods}

Plant Material and Fungal Isolation. One hundred and five seed samples of sesame were collected from the major sesame growing areas of the Punjab, Pakistan (Fig. 1). Seeds for isolating fungi were selected randomly from within a batch and $50 \%$ of seeds were surface sterilized in $5 \% \mathrm{NaOCl}$ for 2 mins. Surface sterilized and unsterilized seeds were placed at the rate of 25 seeds into $90 \mathrm{~mm}$ diameter Petri dishes with three layers of well-moistened filter paper discs (Whatman ${ }^{\mathrm{TM}}$ 1001-090 Grade 1). Petri dishes were incubated at $22 \pm 2^{\circ} \mathrm{C}$ for seven days with an alternate cycle of light and darkness (12 h each) in a Versatile Environmental Test Chamber (Sanyo, Japan); illumination was provided by $55 \mathrm{~W}$ fluorescent lights (Sylvania, Germany) giving a light intensity of $125-130 \mu \mathrm{mol} \mathrm{m}^{-2} \mathrm{~s}^{-1}$. The experiment was performed in triplicate. After incubation, emerging fungal colonies were counted and isolated onto potato dextrose agar (PDA, Oxoid, UK) amended with $100 \mathrm{mg} \mathrm{L}^{-1}$ streptomycin (Singleton et al., 1993). Isolates were maintained on PDA and identified on the basis of morphological characters (Ellis, 1971, 1976; Simmons, 2007).

Isolation frequency $(\mathrm{Fr})$ and relative density (RD) of fungi in and on seeds were calculated as follows:

$$
\operatorname{Fr}(\%)=\frac{(\mathrm{ns})}{\mathrm{N}} \times 100 \quad \mathrm{RD}(\%)=\frac{(\mathrm{ni})}{\mathrm{N}} \times 100
$$

Where, ns is the number of samples on which a fungus occurred; $\mathrm{N}$ is the total number of seeds sampled; $\mathrm{ni}$ is the number of isolates of a fungal genus/species, and $\mathrm{Ni}$ is the total number of fungal isolates obtained.

Fungal DNA Extraction, PCR amplification, and Sequencing. Genomic DNA of representative isolates of the three most frequent groups of Alternaria (A13, A47, and A215) was extracted by scraping the surface of 14 days old cultures grown on PDA. DNA was extracted from 50 mg mycelium per isolate using "Plant DNeasy Mini Kit" (Qiagen, UK) by homogenizing in liquid nitrogen and following the manufacturer's protocol. DNA concentra- 


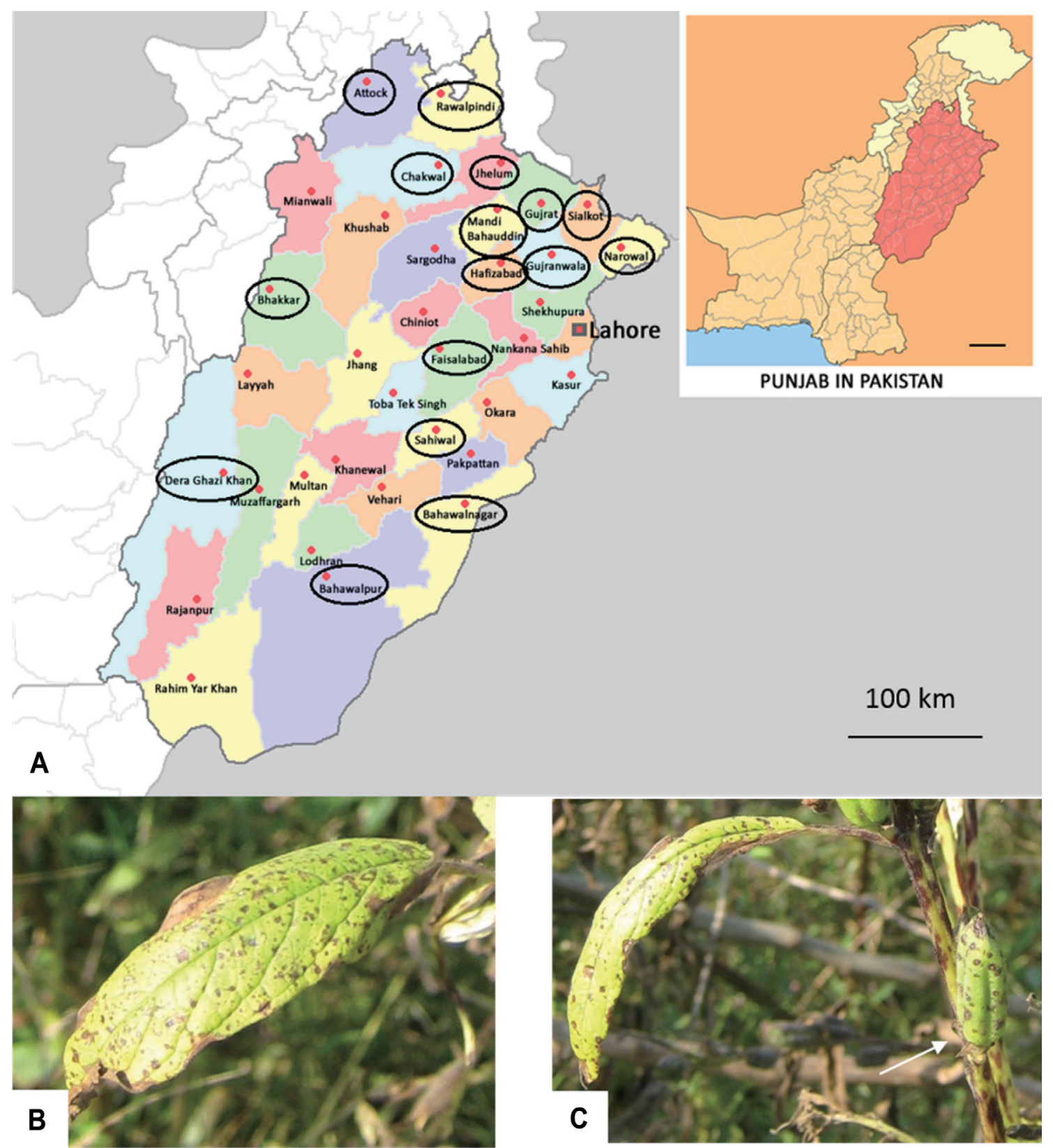

Fig. 1. (A) Sampling sites in the Punjab, Pakistan. (B) Typical leaf blight symptoms on sesame leaves in the field and (C) pods (arrowed) during the sampling in the Punjab, Pakistan.

tion was measured by a NanoDrop ND-1000 spectrophotometer (NanoDrop Technologies Inc., Montchanin, DE, USA) and the final concentration of DNA was adjusted to $100 \mathrm{ng} / \mu \mathrm{l}$ for PCR amplification. The Internal Transcribe Spacer (ITS) region of rDNA and Alt a 1 gene were amplified using ITS1 (TCCGTAGGTGAACCTGCGG) / ITS4 (TCCTCCGCTTATTGATATGC) (White et al., 1990) and Alt-for (ATGCAGTTCACCACCATCGC) / Alt-rev (ACGAGGGTGAYGTAGGCGTC) primers (Hong et al., 2005a), respectively.
PCR was performed in a $25 \mu 1$ reaction mixture containing $12.5 \mu$ BioMix (Bioline), $0.5 \mu 1$ each primer, $2 \mu 1$ template DNA and $9.5 \mu$ pure water. PCR was performed in a MyCycler ${ }^{\mathrm{TM}}$ Thermal cycler (Bio-Rad, USA) with initial denaturation at $95^{\circ} \mathrm{C}$ for 3 mins followed by 35 cycles of $94^{\circ} \mathrm{C}$ for $30 \mathrm{~s}, 55^{\circ} \mathrm{C}$ for $30 \mathrm{~s}$ and $72^{\circ} \mathrm{C}$ for $1 \mathrm{~min}$ and a final elongation step at $72^{\circ} \mathrm{C}$ for 10 min for ITS amplification. For the Alt a 1 gene amplification, an initial denaturation at $94^{\circ} \mathrm{C}$ for $1 \mathrm{~min}$ was followed by 35 cycles of $94^{\circ} \mathrm{C}$ for $30 \mathrm{~s}$, annealing at $57^{\circ} \mathrm{C}$ for $30 \mathrm{~s}, 72^{\circ} \mathrm{C}$ for $1 \mathrm{~min}$, and a final 
extension at $72^{\circ} \mathrm{C}$ for $10 \mathrm{~min}$. Amplified fragments were loaded on an agarose gel $(1 \% \mathrm{w} / \mathrm{v})$ stained with $\mathrm{SYBR}^{\circledR}$ Safe DNA gel stain (Invitrogen, USA), visualized under UV light and purified with a "Qiaquick PCR Purification kit” (Qiagen, UK), following the manufacturer's protocol. Amplicons were sequenced by Source BioScience (UK) in both directions and the sequences analyzed using MEGA 7 software (Kumar et al., 2016) and blasted against the NCBI database (https://blast.ncbi.nlm.nih.gov/Blast.cgi).

Phylogenetic Analysis. The phylogeny for each genus was reconstructed using the Maximum Likelihood (ML) method based on the Tamura-Nei model (Tamura and Nei, 1993). The bootstrap consensus tree inferred from 500 replicates was taken to represent the evolutionary history of the taxa analyzed. Branches corresponding to partitions reproduced in less than $50 \%$ bootstrap replicates were collapsed. Initial tree(s) for the heuristic search were obtained automatically by applying Neighbor-Join and BioNJ algorithms to a matrix of pairwise distances estimated using the Maximum Composite Likelihood (MCL) approach, and then selecting the topology with a superior log likelihood value. Evolutionary analyses were conducted in MEGA 7 (Kumar et al., 2016).

Pathogenicity Testing. Spore suspensions were prepared by flooding PDA cultures with sterile distilled water amended with two drops of Tween 20 per $100 \mathrm{ml}$ and the spore concentration was adjusted to $10^{6}$ conidia $\mathrm{ml}^{-1}$ using replicate hemocytometer counts. For the pathogenicity test, sesame seeds were sown in a glasshouse under natural light conditions ( $14 \mathrm{~h}$ photoperiod, $25-32^{\circ} \mathrm{C}$ ). Ten sterilized seeds per pot were sown in a soil - sand - farmyard manure mixture $(2: 1: 1 \mathrm{w} / \mathrm{w})$. Plants, 4-weeks old, were sprayed to run off with the spore suspension using a spray bottle and covered with plastic bags to maintain high humidity for $24 \mathrm{~h}$. Symptoms were evaluated 7 days after inoculation. Plants were rated for the presence $(+)$ or absence $(-)$ of 2to 5-mm-diameter spots of irregular shape, dark brown to grey in color and surrounded by a bright yellow margin. Three replicate pots for each isolate were tested. To verify the ability of the Alternaria spp. isolates to colonize the
A13
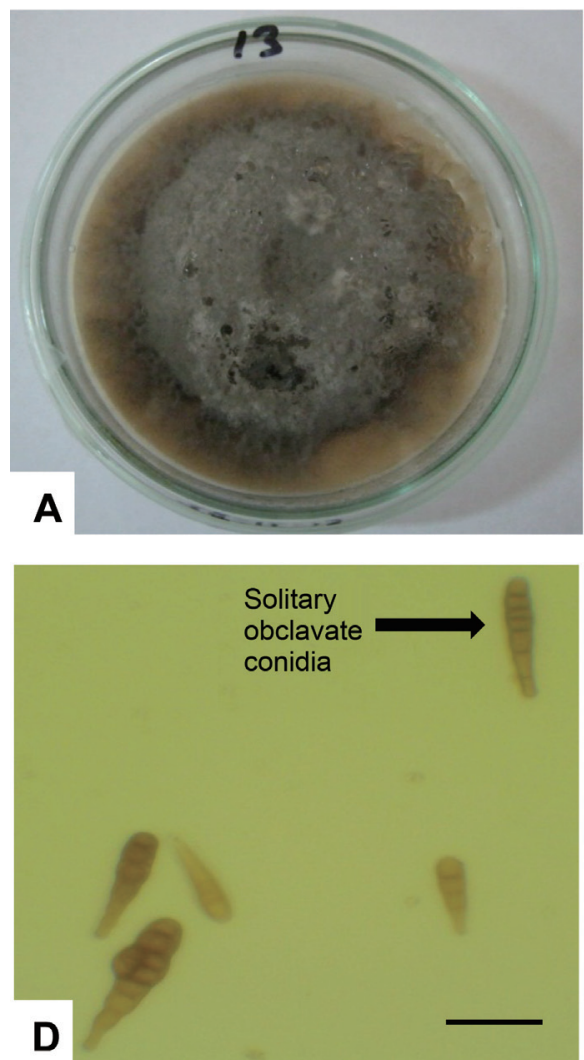

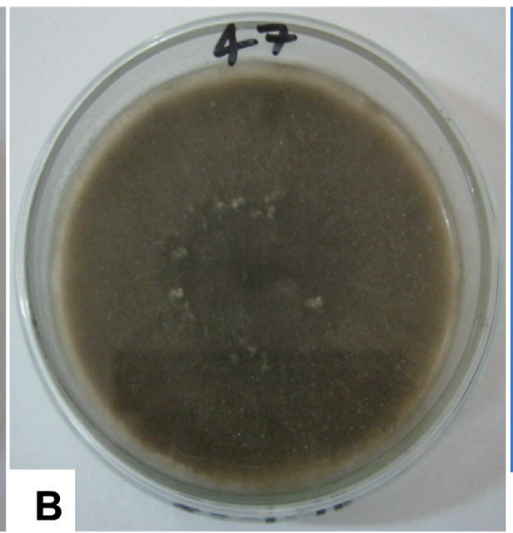

A47

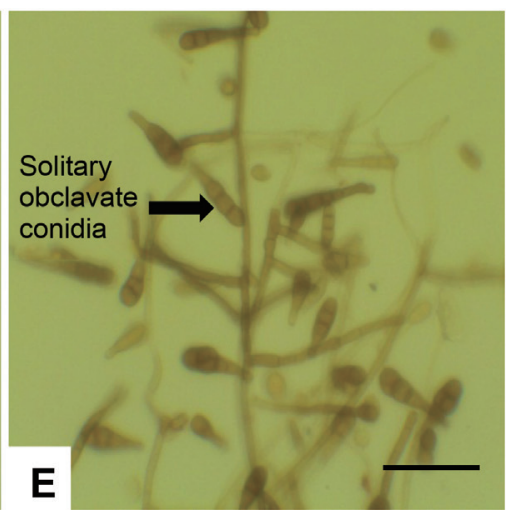

A215
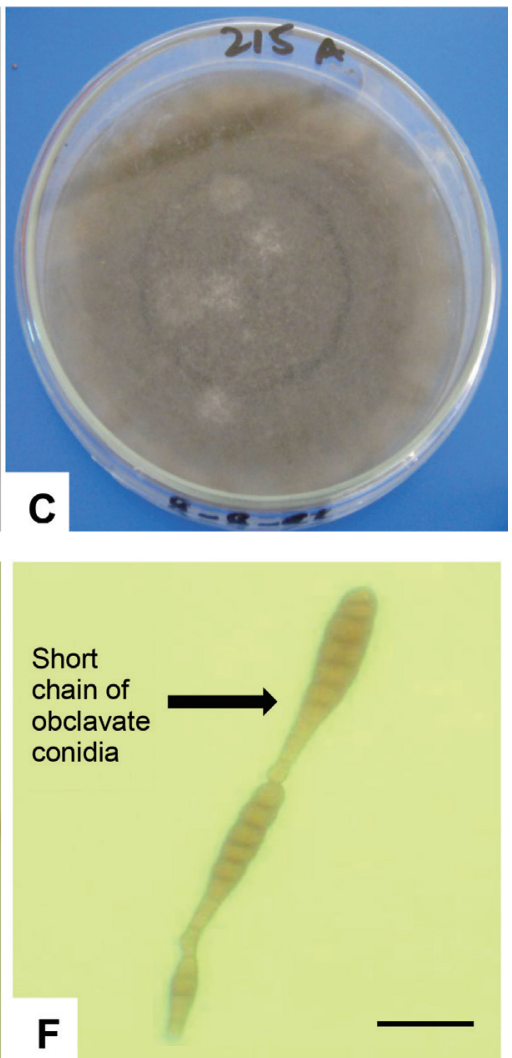

Fig. 2. (A-C) Colony morphology of three most frequent Alternaria isolates (A13, A47, A215) obtained from sesame seeds on PDA. (DF) Conidia of three most frequent Alternaria isolates $(\mathrm{Bar}=10 \mu \mathrm{m})$. 
host tissues, re-isolations were made from the lesions onto PDA to fulfill Koch's postulates. In addition, disease severity (DS) was scored on a revised rating system from Zhao et al. (2016): $0=$ no symptoms on leaves; $1=0-25 \%$ infection on leaves; $2=25-50 \%$ infection on leaf area. Disease severity index (DSI) was calculated as $\sum$ (disease severity scale points $\times$ number of plants at each scale point) / (total number of seedlings assessed $\times$ disease severity scale of the highest scale point observed) $\times 100$ (Zhao et al., 2014).

Effect of Culture Filtrate on Seed Germination and Seedling Growth. Erlenmeyer flasks containing $50 \mathrm{ml}$ of potato dextrose broth (Sigma Aldrich, USA; catalog number P-6685; prepared using $24 \mathrm{~g} / \mathrm{L}$ and autoclaved at $121^{\circ} \mathrm{C}$ for 15 minutes) were inoculated with the test fungi and incubated at $28^{\circ} \mathrm{C}$. After 5 days, the culture broth and fungal mycelia were carefully separated. A $50 \mathrm{ml}$ volume of 3:2:1 $(\mathrm{v} / \mathrm{v} / \mathrm{v})$ ethyl acetate: chloroform: methanol was added to each flask containing culture broth, followed by shaking overnight on a rotary shaker. Extracts were centrifuged at
$5000 \mathrm{rpm}$ for 30 minutes and the supernatant incubated in a water bath at $45^{\circ} \mathrm{C}$ for $8-10 \mathrm{~h}$ to concentrate the extract to a volume of $10 \mathrm{ml}$ (Jaiswal et al., 2012).

Sesame seeds were surface sterilized in 5\% sodium hypochlorite for two minutes followed by 3 rinses in sterile distilled water before suspending in culture filtrates $(10$ $\mathrm{ml})$. Following incubation at $28 \pm 2^{\circ} \mathrm{C}$ for $24 \mathrm{~h}$, seeds were removed from the filtrate extract and washed once in sterile distilled water. Treated seeds were plated on $1.5 \%$ water agar in $90 \mathrm{~mm}$ diameter Petri dishes, with 10 seeds per dish. Control seeds were treated with distilled water prior to plating on $1.5 \%$ water agar. After 7 days of incubation, shoot and root lengths were recorded. In addition, a vigor index was calculated (Jalander and Gachande, 2012) following the formulae:

Germination $\%=$ Germinated seeds of treatment /Germinated seeds of control $\times 100$

Vigor index $=$ Seed germination $(\%)$ $\times$ Seedling Length (Shoot + Root Length)

Table 1. Morphological characterization, isolation frequency and relative density of Alternaria isolates from sesame seeds

\begin{tabular}{|c|c|c|c|c|c|c|c|c|}
\hline \multirow{2}{*}{$\begin{array}{l}\text { Isolate } \\
\text { code }\end{array}$} & \multirow[b]{2}{*}{ Name of fungi } & \multirow{2}{*}{$\begin{array}{l}\text { Origin } \\
\text { (city) }\end{array}$} & \multicolumn{3}{|c|}{ Non sterilized seeds } & \multicolumn{3}{|c|}{ Surface sterilized seeds } \\
\hline & & & $\begin{array}{l}\text { No. of } \\
\text { isolates }\end{array}$ & $F r$ & $R D$ & $\begin{array}{l}\text { No. of } \\
\text { isolates }\end{array}$ & $\mathrm{Fr}$ & $R D$ \\
\hline A6 & Alternaria dianthi & Sialkot & 5 & 10 & 2.14 & 4 & 6 & 2.06 \\
\hline A13 & Alternaria sesami & Sialkot & 58 & 24 & 24.79 & 32 & 40 & 16.49 \\
\hline A19 & Alternaria citri & Sialkot & 13 & 18 & 5.56 & 5 & 8 & 2.58 \\
\hline A47 & Alternaria longipes & Gujranwala & 17 & 78 & 7.26 & 19 & 40 & 9.79 \\
\hline A91 & Alternaria dianthicola & Gujranwala & 17 & 24 & 7.26 & 7 & 10 & 3.61 \\
\hline A166 & Alternaria brassicicola & Gujranwala & 6 & 8 & 2.56 & 32 & 40 & 16.49 \\
\hline A181 & Alternaria solani & Gujranwala & 7 & 10 & 2.99 & 3 & 2 & 1.55 \\
\hline A183 & Alternaria raphanin & Gujranwala & 0 & 0 & 0.00 & 1 & 2 & 0.52 \\
\hline A196 & Alternaria alternata & Gujranwala & 13 & 18 & 5.56 & 5 & 6 & 2.58 \\
\hline A203 & Alternaria dianthicola & Hafizabad & 16 & 22 & 6.84 & 4 & 6 & 2.06 \\
\hline A215 & Alternaria brassicae & Hafizabad & 18 & 26 & 7.69 & 30 & 26 & 15.46 \\
\hline A217 & Alternaria citri & Hafizabad & 2 & 2 & 0.85 & 0 & 0 & 0.00 \\
\hline A218 & Alternaria infectoria & Hafizabad & 3 & 4 & 1.28 & 0 & 0 & 0.00 \\
\hline A220 & Alternaria sesamicola & Gujrat & 17 & 24 & 7.26 & 6 & 8 & 3.09 \\
\hline A221 & Alternaria helianthi & Gujrat & 9 & 12 & 3.85 & 6 & 8 & 3.09 \\
\hline A228 & Alternaria longissimi & Gujrat & 10 & 14 & 4.27 & 3 & 4 & 1.55 \\
\hline A236 & Alternaria raphanin & Gujrat & 4 & 4 & 1.71 & 1 & 2 & 0.52 \\
\hline A239 & Alternaria tenuissima & Attock & 7 & 10 & 2.99 & 0 & 0 & 0.00 \\
\hline A249 & Alternaria triticina & Attock & 0 & 0 & 0.00 & 19 & 26 & 9.79 \\
\hline A261 & Alternaria radicina & Mandi Bahuddin & 4 & 4 & 1.71 & 4 & 8 & 2.06 \\
\hline A263 & Alternaria pluriseptata & Mandi Bahuddin & 3 & 6 & 1.28 & 2 & 2 & 1.03 \\
\hline A267 & Alternaria cinerariae & Mandi Bahuddin & 2 & 4 & 0.85 & 5 & 8 & 2.58 \\
\hline A272 & Alternaria chlamydospora & Mandi Bahuddin & 3 & 4 & 1.28 & 6 & 6 & 3.09 \\
\hline
\end{tabular}

$F r=$ Isolation frequency; $R D=$ relative density. 


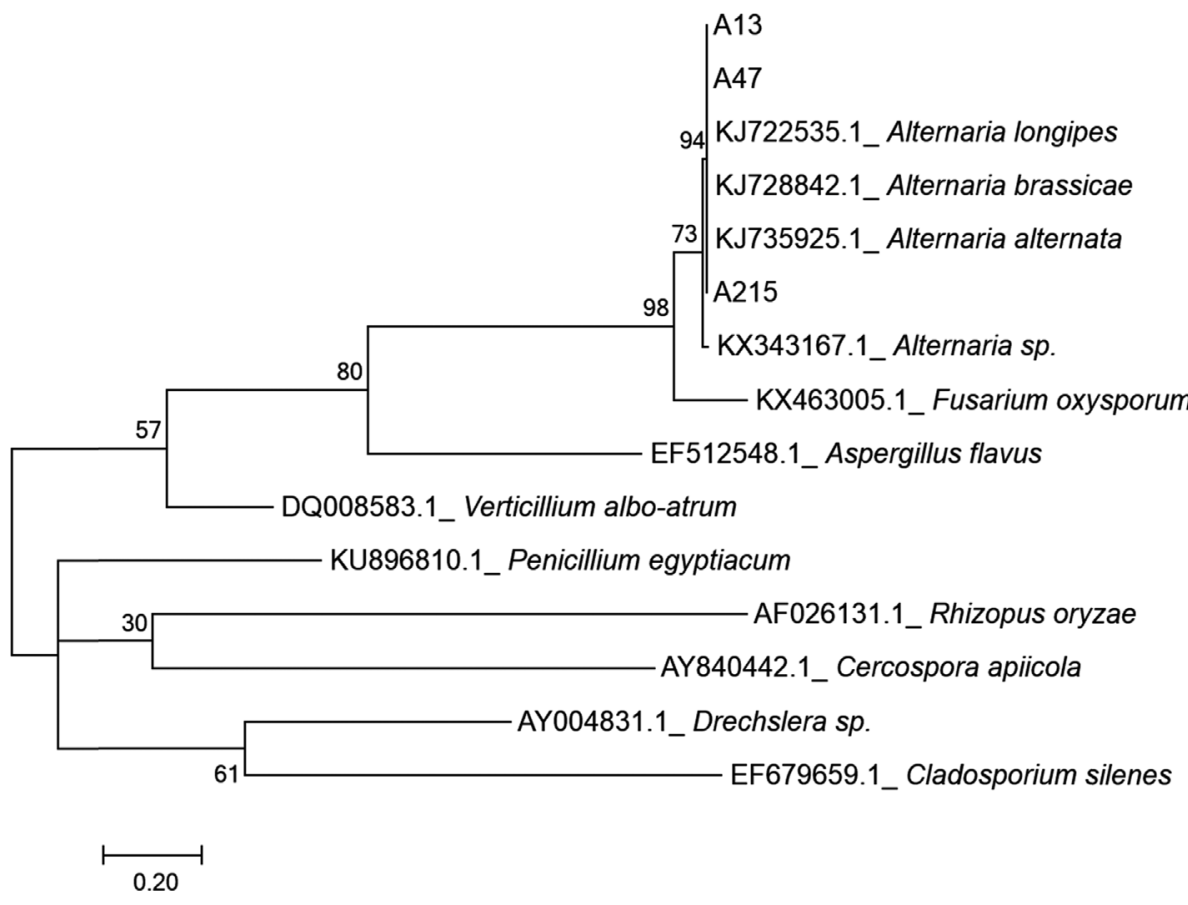

Fig. 3. Maximum likelihood phylogenetic tree obtained from consensus sequences of Alternaria isolates from sesame seeds using ITS rDNA primers. Numbers above the branches are bootstrap values from 500 replicates. The scale indicates the genetic distance between the species.

\section{Results}

Morphological Identification of Alternaria species. A total of 428 isolates of Alternaria were recovered from sesame seeds collected in the Punjab, Pakistan. Seeds were selected from plants exhibiting blight symptoms on leaves (Fig. 1B) and pods (Fig. 1C). These isolates were cultured to homogeneity: all isolates developed loose, cottony and greyish-green to olive brown colonies on PDA after incubation at $25^{\circ} \mathrm{C}$ for 7 days in the dark (Fig. 2A, B, C). Isolates were grouped morphologically, based on well-established features of Alternaria species, focusing on colony characteristics and conidial structure (Fig. 2). Based on these features, the isolates were placed into 36 morphological groups and identified as far as possible. Isolates produced conidia as solitary or in short chains. Conidia were narrowobclavate, ovoid or ellipsoid with 1-2 longi-septa.

The mean isolation frequency and relative density of each isolate form was determined in 100 non-surface sterilized and in 100 surface sterilized seeds. It was observed that majority of isolates were obtained from Gujranwala followed by Hafizabad, Gujrat and Mandi Bahuddin. Quantitatively three isolate groups (A13, A47, A215) were found most frequently (Table 1) and selected for further analyses.

Identification by DNA sequencing. PCR amplification of the ITS regions of rDNA yielded fragments of $\sim 550 \mathrm{bp}$ from all tested Alternaria isolates. PCR of the Alt a 1 gene gave fragments of $\sim 500 \mathrm{bp}$ in length from all isolates. BLAST searches on NCBI showed the ITS sequences to be $100 \%$ identical to those of Alternaria isolates described as "Alternaria sp." but also matched precisely with named species including $A$. alternata, A. longipes and A. brassicae. Phylogenetic analysis using ITS sequences failed to differentiate the isolates, grouping all 3 into a single clade (Fig. 3), with the reference sequences of $A$. alternata (KJ735925.1), A. brassicae (KJ728842.1) and A. longipes (KJ722535.1) obtained from GenBank. In contrast, sequences of the Alt a 1 gene showed $>99 \%$ homology with Alternaria alternata and phylogenetic analysis placed the isolates in a clade close to the reference sequence of $\mathrm{Al}$ ternaria alternata (KP123850.1; Fig. 4). Similarly, some morphological characters of selected isolates (A13, A47 and A215) showed homology with colony and conidial characters of $A$. alternata. However, the Alt a 1 sequence of strain A13 indicated that it was distinct from the A. alternata clade. Sequences from the isolates obtained in this work were submitted to GenBank (Table 2).

Pathogenicity Tests. Seven days after inoculation with a spore suspension of the Alternaria isolates, brown lesions surrounded by yellow haloes began to develop on sesame leaves; disease symptoms gradually spread from leaf margins to the midveins, similar to symptoms observed in the sesame fields during the sample collection. In a later stage, blight extended to the center of the leaves and plants be- 


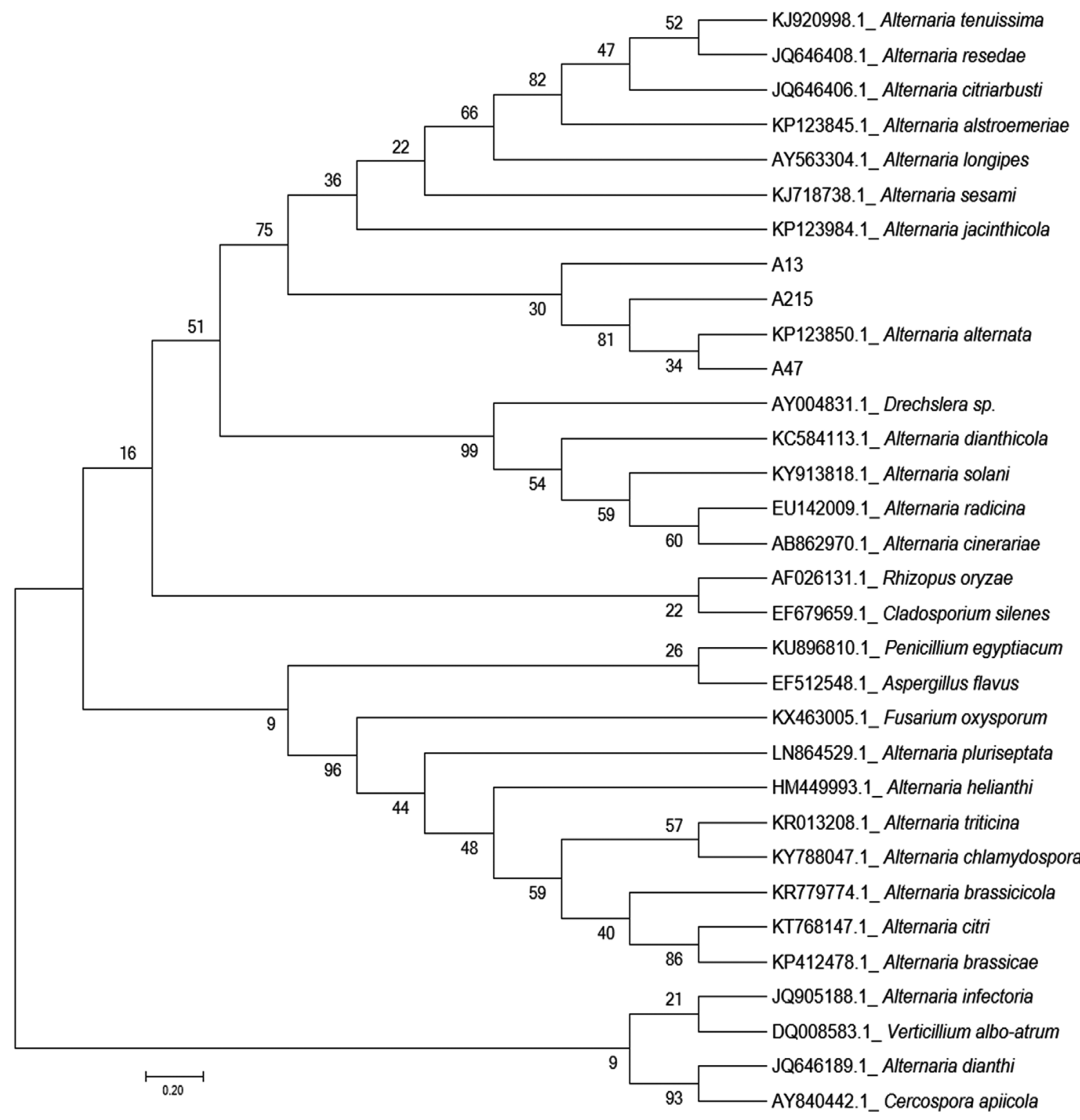

Fig. 4. Maximum likelihood phylogenetic tree obtained from consensus sequences of Alternaria isolates from sesame seeds using Altforward and reverse primers. Numbers above the branches are bootstrap values from 500 replicates. The scale indicates the genetic distance between the species.

Table 2. Molecular Identification of three most frequent Alternaria isolates obtained from sesame seeds

\begin{tabular}{|c|c|c|c|c|c|c|}
\hline \multirow{2}{*}{$\begin{array}{l}\text { Isolate } \\
\text { code }\end{array}$} & \multirow{2}{*}{$\begin{array}{l}\text { Origin } \\
\text { (city) }\end{array}$} & \multirow{2}{*}{$\begin{array}{l}\text { Morphological } \\
\text { identification }\end{array}$} & \multicolumn{2}{|c|}{ Molecular identification } & \multicolumn{2}{|c|}{ NCBI accession no. } \\
\hline & & & ITS & Alt a 1 & ITS & Alt a 1 \\
\hline A13 & Sialkot & Alternaria sesami & Alternaria sp. & Alternaria alternata & KY190101 & KY124234 \\
\hline A47 & Gujranwala & Alternaria longipes & Alternaria sp. & Alternaria alternata & KY190102 & KY124235 \\
\hline A215 & Hafizabad & Alternaria brassicae & Alternaria sp. & Alternaria alternata & KY190103 & KY124236 \\
\hline
\end{tabular}

came defoliated (Fig. 5). Extended necrosis surrounded by yellowing was usually observed on diseased leaves. Pathogenicity tests confirmed that all tested isolates were virulent leaf blight pathogens, the most virulent being A13 (Table 3). No symptoms developed on control plants. The Alternaria isolates were reisolated from symptomatic leaves of inocu- 


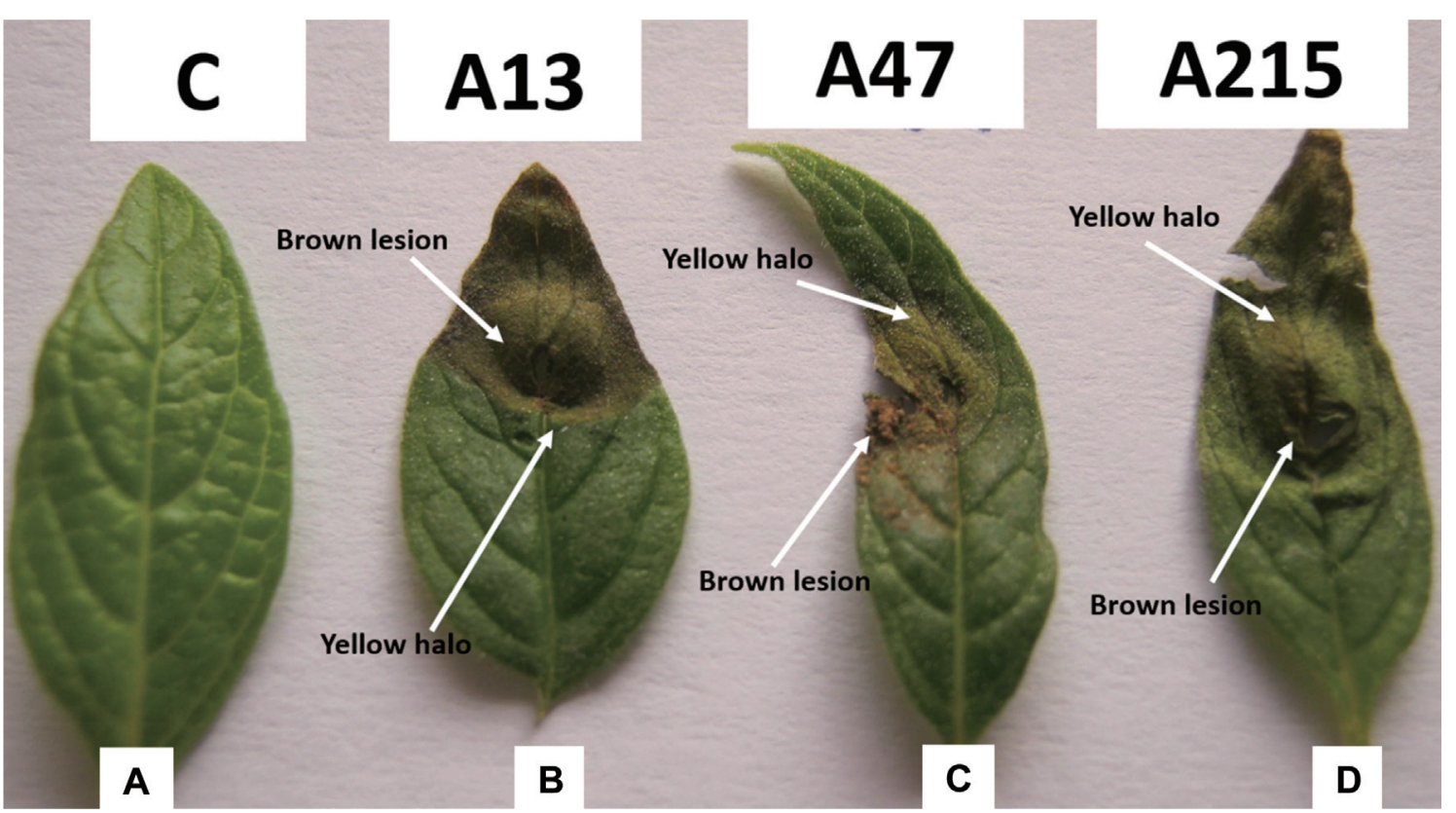

Fig. 5. Symptoms produced by three isolates of Alternaria on leaves of sesame plants 7 days after inoculation. (A) Control; (B) A13; (C) A47; (D) A215.

Table 3. Pathogenicity test of Alternaria isolates (A13, A47 and A215) on sesame seedlings

\begin{tabular}{cccccccccc}
\hline Infection & $\begin{array}{c}\text { Total } \\
\text { leaves }\end{array}$ & $\begin{array}{c}\text { Infected } \\
\text { leaves }\end{array}$ & $\begin{array}{c}\text { Disease incidence } \\
(\%)\end{array}$ & $\begin{array}{c}\text { Disease severity } \\
\text { incidence }\end{array}$ & $\begin{array}{c}\text { No. of } \\
\text { lesions/leaf }\end{array}$ & $\begin{array}{c}\text { Area of lesions } \\
(\mathrm{cm})\end{array}$ & $\begin{array}{c}\text { Area of } \\
\text { leaf }\end{array}$ & $\begin{array}{c}\text { Infection } \\
(\%)\end{array}$ & $\begin{array}{c}\text { Rating } \\
\text { scale }\end{array}$ \\
\hline A13 & 7 & 2 & 28.5 & 28.57 & 2 & 0.49 & 1.55 & 31.61 & 2 \\
A47 & 9 & 2 & 22.2 & 12.11 & 2 & 0.22 & 1.16 & 18.97 & 1 \\
A215 & 10 & 1 & 10 & 20 & 1 & 0.5 & 1.19 & 42.02 & 2 \\
\hline
\end{tabular}

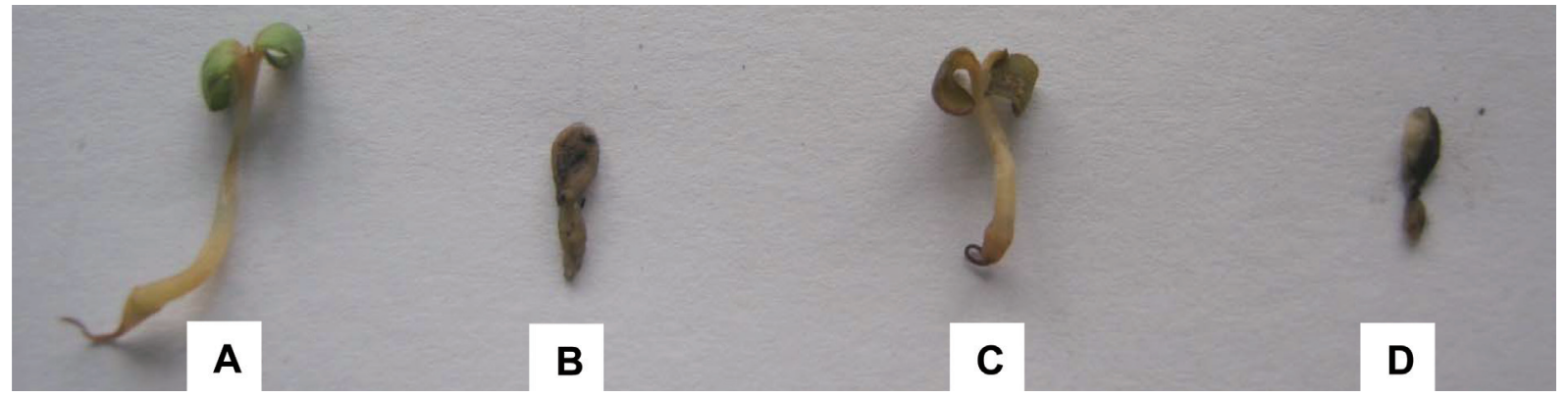

Fig. 6. Effect of cultural filtrates of Alternaria isolates on the germination of sesame seeds after 7 days of incubation. (A) Control; (B) A13; (C) A47; (D) A215.

lated plants, but not from any of the control plants.

Effect of Culture Filtrates on Seed Germination. Seed germination and vigor of sesame seedlings were adversely affected by the culture filtrates of isolate A13 (Fig. 6). The reduction in seed germination ranged from $40-60 \%$, while vigor index in samples treated with filtrates of this isolate was $4 \%$ compared with over $62 \%$ in control plants (Table 4 ).

\section{Discussion}

This work clearly demonstrated that Alternaria species are present in a high proportion of sesame seeds collected from various regions in the Punjab, Pakistan, suggesting that there is a potential source of inoculum to initiate disease outbreaks under conditions favorable to pathogen develop- 
Table 4. Effects of culture filtrates from Alternaria isolates (A13, A47 and A215) on germination of sesame seeds and growth of seedings

\begin{tabular}{ccccc}
\hline Treatment & Germination $\%$ & Root length $(\mathrm{cm})$ & Shoot length $(\mathrm{cm})$ & Vigor index \\
\hline A13 & 40.00 & 0.10 & 0.00 & 4.00 \\
A47 & 60.00 & 0.40 & 0.90 & 24.90 \\
A215 & 53.33 & 0.20 & 0.00 & 10.67 \\
Control & 86.67 & 0.70 & 1.50 & 62.17 \\
\hline
\end{tabular}

Vigor index $=$ Seed germination $(\%) \times$ Seedling Length (Shoot + Root Length).

ment. The most common species of Alternaria found in the present work was $A$. alternata. Species delineation within the genus Alternaria requires careful attention in order to determine the range of species causing diseases on a given host.

Amongst the species of Alternaria identified morphologically, three representatives, chosen from the most commonly occurring groups (A13, A47, A215), were initially identified as Alternaria sesami, Alternaria longipes and Alternaria brassicae, respectively, on the basis of conidial morphology and colony characteristics. Identification of Alternaria species based on morphological criteria, however, remains a challenging task, leading to controversy and confusion very often accompanying classification in this genus (Maraite et al., 1998). This problem is especially relevant for the small-spored species, which share morphological characteristics such as having overlapping conidial size ranges (Simmons, 1992). Although the ITS region of rDNA is widely used as a barcode for fungi (Blaalid et al., 2013), the sequences of the Alternaria isolates analyzed here were $100 \%$ identical to those of "Alternaria sp." in Genbank, but were also identical to those of other Alternaria species, including $A$. alternata, A. longipes or $A$. brassicae. It has been recognized that ITS sequences are not always able to differentiate at the species level in the genus Alternaria (Pryor and Michailides, 2002; Shipunov et al., 2008; Zur et al., 2002).

In contrast, use of the partial coding sequence of the $\mathrm{Al}$ ternaria major allergen gene (Alt a 1 gene) in PCR enabled accurate identification to the species level, confirming that all three isolates tested were Alternaria alternata, in agreement with other workers studying different hosts for this genus of pathogens (Guo-yin et al., 2013; Paul et al., 2015; Skóra et al., 2015). It has been suggested that the Alt a 1 gene sequence evolved 3.8 times faster and contained 3.5 times more parsimony-informative sites than glyceraldehyde-3-phosphate dehydrogenase ( $g p d$ ) sequences, strongly supporting the use of this part of the genome for species identification in Alternaria (Hong et al., 2005a).

Based on this work, therefore, it can be concluded that
Alternaria alternata is a destructive pathogen causing leaf blight on sesame in the Punjab, Pakistan. The incidence of Alternaria alternata in sesame seed was high compared to other species of Alternaria isolated from this host plant. Most Alternaria spp., including A. alternata, exhibit considerable morphological plasticity depending on cultural conditions, including substrate, temperature, light and humidity. These fungi, therefore, in particular A. alternata, can be frequently misidentified when relying on morphological characteristics alone (Misaghi et al., 1978; Roberts et al., 2000; Simmons, 1992). Moreover, the inoculation tests carried out with the three isolates of Alternaria alternata confirmed pathogenicity and virulence, with the development of leaf blight in sesame, similar to the results reported with $A$. longipes by Shoaib et al (2014).

The wide variability among different Alternaria species from different hosts has been reported previously (Kumar et al., 2008; Pryor and Gilbertson 2000; Pryor and Michailides, 2002; Quayyum et al., 2005). Among the different diseases caused by species in the genus Alternaria, leaf blight disease is one of the most important, causing yield loss in the range of $32-57 \%$ per annum in canola, for example (Conn and Tewari, 1990). In the present study, symptoms of the disease on sesame include the presence of irregular, often circular brown to dark brown colored spots on the leaves, with concentric lines inside the spots which are in agreement with the findings of Valkonen and Koponen (1990) who reported that individual circular spots may coalesce to form large patches, resulting in leaf blight of Chinese cabbage. In some infections, small dark colored spots are formed on pods and young shoots of Chinese cabbage.

An important conclusion drawn from the work presented in this paper is that identification of Alternaria spp. on the basis of morphological characteristics alone is unreliable for correct determination of species. More stringent identification was possible using species-specific primers, which are required in diagnostics for sesame seed testing: ITS sequences were not sufficiently discriminatory to separate species. 


\section{Acknowledgments}

This work was supported by the Higher Education Commission (HEC) of Pakistan under the National Research Program for Universities (NRPU) project No. 20-5166. Moreover, HEC is also acknowledged for providing funds to the first author (IRSIP No. 1-8/HEC/HRD/20143411) to visit Department of Plant and Soil Science, University of Aberdeen, Scotland, UK. First two authors are thankful to the Govt. of Scotland for providing the import license for three Alternaria isolates under Directive 2008/61/EC and Scottish License No. PH/9/2015.

\section{References}

Ashri, A. 2007. Sesame (Sesamum indicum L.). In: Genetic resources, chromosomes engineering, and crop improvement, Volume 4, ed. by R. J. Singh, pp. 231-289. CRC Press, Boca Raton, FL, USA.

Ashri, A. 1998. Sesame Breeding. In: Plant breeding reviews, Volume 16, ed. by J. Janick, pp. 179-228. John Wiley \& Sons, Inc., Oxford, UK.

Blaalid, R., Kumar, S., Nilsson, R. H., Abarenkov, K., Kirk, P. M. and Kauserud, H. 2013. ITS1 versus ITS2 as DNA metabarcodes for fungi. Mol. Ecol. Resour. 13:218-224.

Chohan, J. S. 1978. Diseases of oil seed crops, future plans and strategy for control under small holdings. Indian Phytopathol. 31:1-15.

Conn, K. L. and Tewari, J. P. 1990. Survey of Alternaria blackspot and Sclerotinia stem rot in central Alberta in 1989. Can. Plant Dis. Surv. 70:66-67.

Ellis, M. B. 1971. Dematiaceous hyphomycetes. Commonwealth Mycological Institute, Kew, Surrey, UK. 608 pp.

Ellis, M. B. 1976. More dematiaceous hyphomycetes. Commonwealth Mycological Institute, Kew, Surrey, UK. 507 pp.

Enikuomehin, O. A., Olowe, V. I. O., Alao, O. S. and Atayese, M. O. 2002. Assessment of Cercospora leaf spot disease of sesame in different planting dates in South-Western, Nigeria. Moor J. Agric. Res. 3:76-82.

FAO. 2014. FAOSTAT databases. URL http://www.fao.org/faostat/en/\#data/QC/.

Farhan, H. N., Abdullah, B. H. and Hameed, A. T. 2010. The biological activity of bacterial vaccine of Pseudomonas putida 2 and Pseudomonas fluorescens 3 isolates to protect sesame crop (Sesamum indicum) from Fusarium fungi under field conditions. Agric. Biol. J. N. Am. 1:803-811.

Grubben, G. J. H. and Denton, O. A. 2004. Plant resources of tropical Africa 2: vegetables. PROTA Foundation, Wageningen, Netherlands. 668 pp.

Guo-yin, T., Zhi-ling, Y., Zhi-lin, Y. and Shou-an, Z. 2013. Morphological, molecular and pathogenic characterization of Alternaria longipes, the fungal pathogen causing leaf spot on Atractylodes macrocephala. Afr. J. Microbiol. Res. 7:2589-
2595.

Hong, S. G., Cramer, R. A., Lawrence, C. B. and Pryor, B. M. 2005a. Alt a 1 allergen homologs from Alternaria and related taxa: analysis of phylogenetic content and secondary structure. Fungal Genet. Biol. 42:119-129.

Hong, S. G., Liu, D. and Pryor, B. M. 2005b. Restriction mapping of the IGS region in Alternaria spp. reveals variable and conserved domains. Mycol. Res. 109:87-95.

Jaiswal, S., Saini, R., Sangani, S. R., Tiwari, S., Agrawal, M. and Agrawal, M. K. 2012. Antibacterial activity of five fungal strains isolated from a leguminous soil field against nitrogenfixing bacteria. Ann. Biol. Res. 3:2829-2837.

Jalander, V. and Gachande, B. D. 2012. Effect of fungal metabolites of some rhizosphere soil fungi on seed germination and seedling growth of some pulses and cereals. Sci. Res. Repot. 2:265-267.

Johnson, L. A., Suleiman, T. M. and Lusas, E. W. 1979. Sesame protein: a review and prospectus. J. Am. Oil Chem. Soc. 56:463-468.

Kahyaoglu, T. and Kaya, S. 2006. Modeling of moisture, color and texture changes in sesame seeds during the conventional roasting. J. Food Eng. 75:167-177.

Kolte, S. J. 1985. Diseases of annual edible oil seed crops. In: Rapeseed, mustard, safflower and sesame diseases, pp. 221232. CRC Press Inc, Boca Raton, FL, USA.

Kumar, V., Haldar, S., Pandey, K. K., Singh, R. P., Singh, A. K. and Singh, P. C. 2008. Cultural, morphological, pathogenic and molecular variability amongst tomato isolates of Alternaria solani in India. World J. Microbiol. Biotechnol. 24: 1003-1009.

Kumar, S., Stecher, G. and Tamura, K. 2016. MEGA7: Molecular Evolutionary Genetics Analysis version 7.0 for bigger datasets. Mol. Biol. Evol. 33:1870-1874.

Lubaina, A. S. and Murugan, K. 2013. Physiological and biochemical characterization of Senna alata (L.) Roxb. leaf extract - a plant based fungicide against Alternaria leaf spot in sesame. World J. Pharm. Pharm. Sci. 2:5790-5801.

Maraite, H., Di Zinno, T., Longree, H., Daumerie, V. and Duveiller, E. 1998. Fungi associated with foliar blight of wheat in warm areas. In: Helminthosporium blights of wheat: spot blotch and tan spot, eds. by E. Duveiller, H. H. Dubin, J. Reeves and A. McNab, pp. 293-300. CIMMYT, Mexico.

Mbah, M. C. and Akueshi, C. O. 2000. Effect of seed borne fungi Aspergillus flavus and Aspergillus niger on the germinability of sesame seeds. Niger. J. Hort. Soc. 4:57-64.

Mbah, M. C. and Akueshi, C. O. 2001. Some physico-chemical changes induced by Aspergillus flavus and Aspergillus niger on Sesamum indicum and Sesamum radiatum. J. Sci. Agric. Food Technol. Environ. 1:65-69.

Misaghi, I. J., Grogan, R. G., Duniway, J. M. and Kimble, K. A. 1978. Influence of environment and culture media on spore morphology of Alternaria alternata. Phytopathology 68:2934.

Naik, M. K., Patil, R. G., Suvarna and Ajithkumar, K. 2004. Yield 
loss model and blight prediction model in Alternaria blight of sesame. Indian Phytopathology 57:106 (Abstract).

Obiajunwa, E. I., Adebiyi, F. M. and Omode, P. E. 2005. Determination of essential minerals and trace elements in Nigerian sesame seeds, using TXRF Technique. Pak. J. Nutr. 4:393395.

Ojiambo, P. S. 1997. Cultural studies and epidemiology of Alternariasesami and significance of sesame (Sesamum indicum L.) seed transmission and plant age on Alternaria leaf spot severity. M.Sc. thesis. University of Nairobi, Nairobi, Kenya. 111 pp.

Pastorello, A. E., Varin, E., Farioli, L., Pravettoni, V., Ortolani, C., Trambaioli, C., Fortunato, D., Giuffrida, M. G., Rivolta, F., Robino, A., Calamari, A. M., Lacava, L. and Conti, A. 2001. The major allergen of sesame seeds (Sesamum indicum) is a 2S albumin. J. Chromatogr. B Biomed. Sci. Appl. 756:85-93.

Paul, N. C., Deng, J. X., Lee, H. B. and Yu, S. H. 2015. Characterization and pathogenicity of Alternaria burnsii from seeds of Cucurbita maxima (Cucurbitaceae) in Bangladesh. Mycobiology 43:384-391.

Pryor, B. M. and Gilbertson, R. L. 2000. Molecular phylogenetic relationship amongst Alternaria species and related fungi based upon analysis of nuclear ITS and mt SSU rDNA sequences. Mycol. Res. 104:1312-1321

Pryor, B. M. and Michailides, T. J. 2002. Morphological, pathogenic, and molecular characterization of Alternaria isolates associated with Alternaria late blight of pistachio. Phytopathology 92:406-416.

Quayyum, H. A., Dobinson, K. F. and Traquair, J. A. 2005. Conidial morphology, virulence, molecular characterization, and host-parasite interactions of selected Alternaria panax isolates on American ginseng. Can. J. Bot. 83:1133-1143.

Rao, N. R. and Vijayalakshmi, M. 2000. Studies on Alternaria sesami pathogenic to sesame. Microbiol. Res. 155:129-131.

Richardson, M. J. 1979. An annotated list of seed borne diseases. International Seed Testing Association, Zurich, Switzerland. 320 pp.

Roberts, R. G., Reymond, S. T. and Andersen, B. 2000. RAPD fragment pattern analysis and morphological segregation of small-spored Alternaria species and species groups. Mycol. Res. 104:151-160.

Saha, D., Fetzner, R., Burkhardt, B., Podlech, J., Metzler, M., Dang, H., Lawrence, C. and Fischer, R. 2012. Identification of a polyketide synthase required for alternariol $(\mathrm{AOH})$ and alternariol-9-methyl ether (AME) formation in Alternaria alternata. PLoS One 7:e40564.

Schrader, T. J., Cherry, W., Soper, K., Langlois, I. and Vijay, H. M. 2001. Examination of Alternaria alternata mutagenicity and effects of nitrosylation using the Ames Salmonella Test. Teratog., Carcinog. Mutagen. 21:261-274.

Shahidi, F., Liyana-Pathirana, C. M. and Wall, D. S. 2006. An- tioxidant activity of white and black sesame seeds and their hull fractions. Food Chem. 99:478-483.

Shipunov, A., Newcombe, G., Raghavendra, A. K. and Anderson, C. L. 2008. Hidden diversity of endophytic fungi in an invasive plant. Am. J. Bot. 95:1096-1108.

Shoaib, A., Akhtar, N., Akhtar, S. and Hafeez, R. 2014. First report of Alternaria longipes causing leaf spot of potato cultivar sante in Pakistan. Plant Dis. 98:1742.

Simmons, E. G. 2007. An identification manual. CBS Fungal Biodiversity Centre, Utrecht, Netherlands. 775 pp.

Simmons, E. G. 1992. Alternaria taxonomy: current status, viewpoint, challenge. In: Alternaria biology, plant diseases and metabolites, eds. by J. Chelkowski and A. Visconti, pp. 1-35. Elsevier Science Publishers, Amsterdam, Netherlands.

Singleton, L. L., Mihail, J. D. and Rush, C. M. 1993. Methods for research on soil borne phytopathogenic fungi. 2 nd ed. American Phytopathological Society, St. Paul. 266 pp.

Skóra, J., Otlewska, A., Gutarowska, B., Leszczyńska, J., Majak, I. and Stępień, Ł. 2015. Production of the allergenic protein Alt a 1 by Alternaria isolates from working environments. Int. J. Environ. Res. Public Health 12:2164-2183.

Tamura, K. and Nei, M. 1993. Estimation of the number of nucleotide substitutions in the control region of mitochondrial DNA in humans and chimpanzees. Mol. Biol. Evol. 10:512526.

The Financial Daily. 2017. An open sesame. URL http://www. thefinancialdaily.com/NewsSearchResult/NewsSearchDetail. aspx?NewsId=89195/ [10 April 2017].

Thomma, B. P. 2003. Alternaria spp.: from general saprophyte to specific parasite. Mol. Plant Pathol. 4:225-236.

Valkonen, J. P. T. and Koponen, H. 1990. The seed-borne fungi of Chinese cabbage (Brassica pekinensis), their pathogenicity and control. Plant Pathol. 39:510-516.

White, T. J., Bruns, T., Lee, S. and Taylor, J. W. 1990. Amplification and direct sequencing of fungal ribosomal RNA genes for phylogenetics. In: PCR protocols: a guide to methods and applications, eds. by M. A. Innis, D. H. Gelfand, J. J. Sninsky and T. J. White, pp. 315-322. Academic Press, Inc., New York, USA.

Zhao, B., Yan, J., Zhang, S., Liu, X. and Gao, Z. 2014. Phylogeny and pathogenicity of Fusarium spp. isolated from greenhouse melon soil in Liaoning Province. Saudi J. Biol. Sci. 21:374379.

Zhao, J., Bao, S., Ma, G. and Wu, X. 2016. Characterization of Alternaria species associated with muskmelon foliar diseases in Beijing municipality of China. J. Gen. Plant Pathol. 82:2932.

Zur, G., Shimoni, E., Hallerman, E. and Kashi, Y. 2002. Detection of Alternaria fungal contamination in cereal grains by a polymerase chain reaction-based assay. J. Food Prot. 65:14331440. 